\title{
The National Union Catalog, 1952-1955 Imprints-A Publication in Early Prospect
}

\author{
BY CHARLES W. DAVID
}

A LONG-CHERISHED DREAM of American librarians was finally realized in 1956 when the content of the already existing Library of Congress [printed] Catalog-Books: Authors was expanded, under the title, The National Union Catalog: $A$ Cumulative Author List, to include catalog entries for monographic works of 1956 and later imprint cataloged originally by more than five hundred important cooperating libraries in the United States and Canada. The result was to make available to librarians and to scholars everywhere a bibliography more than twice as rich as its predecessor. In addition, the expanded National Union Catalog shows the locations of many titles in several geographic areas of the United States and Canada.

As a major step in planning for the publication of the National Union Catalog, particularly as a means of estimating the probable size and cost of the proposed publication, it was decided in 1952 that the Union Catalog Division of the Library of Congress should set aside in a separate file all cards for author entries of monographic materials of 1952-1955 imprint, including copies of all appropriate Library of Congress printed cards. This 1952-1955 imprint segment of the National Union Catalog contained 376,000 cards at the beginning of 1956 . By January 1960 it had grown to about 560 ,000 cards, representing about 212,500 main entries on Library of Congress cards, 225,000 different entries from other libraries, and about 100,000 addedentry cross references and duplicate cards. By comparison with older parts of the National Union Catalog, this file
Mr. David is Director, Longwood Library, Kennett Square, Pa., and sometime chairman of the Subcommittee on the National Union Catalog, ALA Committee on Resources of American Libraries.

was editorally in a relatively good condition.

As a result of the demonstrated value of the published National Union Cata$\log$ which began to appear in 1956 and of the fact that the 1952-1955 imprint file formed a compact, separate union catalog which would readily lend itself to efficient editing and publication, the Subcommittee on the National Union Catalog of the ALA Committee on Resources of American Libraries decided in 1959 to sponsor the publication of this 1952-1955 segment as a second step in the hoped-for undertaking which may some day give us the whole vast retrospective National Union Catalog in convenient printed form. Accordingly, the present writer, then chairman of the subcommittee, explored the interest of a large number of representative libraries by means of a questionnaire, the response to which was very encouraging, and arranged to obtain financial backing on a scale adequate to support the editing of the file in a comprehensive manner. The editorial operation was started at the Library of Congress in 1959 and is now near enough to completion to assure publication during the winter of $1960 / 61$. Publication will be by J. W. Edwards, Inc., of Ann Arbor, Michigan. 


\section{Relation to Existing Publications}

The new publication will at a stroke push the coverage of the National Union Catalog back from January 1, 1956 to January 1, 1952. The advantages of making the contents of this file available in book form to Iibraries all over the nation and the world are obvious, namely a great increase in the supply of bibliographical information for identifying, locating, acquiring, and cataloging monographs of the period in question, such as has proved so useful in the National Union Catalog since 1956. For nonmonographic materials, the publication is supplemented by the Union List of Serials (soon to go into a third edition) and, so far as the holdings of the Library of Congress are concerned, by the Catalog of Books Represented by Library of Congress Printed Cards.

The publication will contribute a further demonstration, if such were needed, that only by a cooperative effort of a large number of research libraries can the vast and scattered resources contained in titles held by many libraries be marshalled for convenient reference and scholarly use. No library today can meet the demands of scholarship and research out of its own resources. The $\mathrm{Na}$ tional Union Catalog, 1952-1955, will serve as a key to resources available beyond the library of one's choice and also as an indicator of gaps among research materials still needing to be filled.

\section{SCOPE}

The new publication will contain main entries for all monographic materials of 1952 through 1955 imprint date reported to the Union Catalog Division of the Library of Congress, with the exception of American master's theses, material printed in Oriental languages or in the Cyrillic alphabet, music scores, motion pictures, filmstrips, phonorecords, and books in Braille, but including maps, atlases, microcards, microfilms, etc. Added entries for titles represented by Library of Congress printed cards, essential added-entry cross references for titles not represented by Library of Congress printed cards, and essential straight cross references for all titles will be provided.

\section{EDITING}

The catalog is being edited by the Library of Congress. All obvious duplication of entries is being removed. It is realized, however, that the variation in form and choice of entry among more than five hundred contributing libraries may result in involuntary duplication of an occasional title under various forms of entry. The entries are not being checked for uniformity with the Library of Congress Catalog, though entries which obviously deviate from ALA cataloging rules or Library of Congress practice are being modified. The completeness of bibliographical information varies from title to title and depends on the practice of libraries submitting the catalog cards and on the photographic possibilities of reproduction (e.g., tracings on the verso of catalog cards cannot be shown).

\section{Physical Description and Anticipated Price}

The publication will duplicate the physical pattern of the Catalog of Books Represented by Library of Congress Printed Cards (the so-called Edwards Brothers Catalog), showing, in photo-offset reproduction, eighteen catalog cards to a page, arranged in three columns of six cards each. Each volume will contain 1,000 pages, size $11 \times 81 / 2$ inches, on 25 per cent rag offset paper, in strong buckram binding. It is estimated that the set will contain 540,000 entries, making thirty volumes, and sell at a price of $\$ 420$. Should the set run to more than thirty volumes, which is not anticipated, the price would be increased on a pro rata basis. 